\title{
Vitamin D deficiency 2.0: an update on the current status worldwide
}

\author{
Karin Amrein $\mathbb{1}^{1,2} \cdot$ Mario Scherkl ${ }^{1} \cdot$ Magdalena Hoffmann $\mathbb{1}^{1,3,4} \cdot$ Stefan Neuwersch-Sommeregger ${ }^{5,6} \cdot$

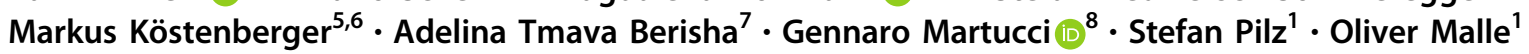

Received: 6 October 2019 / Revised: 17 December 2019 / Accepted: 6 January 2020 / Published online: 20 January 2020

(c) The Author(s), under exclusive licence to Springer Nature Limited 2020

\begin{abstract}
Vitamin D testing and the use of vitamin D supplements have increased substantially in recent years. Currently, the role of vitamin D supplementation, and the optimal vitamin D dose and status, is a subject of debate, because large interventional studies have been unable to show a clear benefit (in mostly vitamin D replete populations). This may be attributed to limitations in trial design, as most studies did not meet the basic requirements of a nutrient intervention study, including vitamin D-replete populations, too small sample sizes, and inconsistent intervention methods regarding dose and metabolites. Vitamin D deficiency (serum 25-hydroxyvitamin D $[25(\mathrm{OH}) \mathrm{D}]<50 \mathrm{nmol} / \mathrm{L}$ or $20 \mathrm{ng} / \mathrm{ml}$ ) is associated with unfavorable skeletal outcomes, including fractures and bone loss. A $25(\mathrm{OH}) \mathrm{D}$ level of $>50 \mathrm{nmol} / \mathrm{L}$ or $20 \mathrm{ng} / \mathrm{ml}$ is, therefore, the primary treatment goal, although some data suggest a benefit for a higher threshold. Severe vitamin D deficiency with a $25(\mathrm{OH}) \mathrm{D}$ concentration below $<30 \mathrm{nmol} / \mathrm{L}$ ( or $12 \mathrm{ng} / \mathrm{ml}$ ) dramatically increases the risk of excess mortality, infections, and many other diseases, and should be avoided whenever possible. The data on a benefit for mortality and prevention of infections, at least in severely deficient individuals, appear convincing. Vitamin D is clearly not a panacea, and is most likely efficient only in deficiency. Given its rare side effects and its relatively wide safety margin, it may be an important, inexpensive, and safe adjuvant therapy for many diseases, but future large and well-designed studies should evaluate this further. A worldwide public health intervention that includes vitamin D supplementation in certain risk groups, and systematic vitamin D food fortification to avoid severe vitamin D deficiency, would appear to be important. In this narrative review, the current international literature on vitamin D deficiency, its relevance, and therapeutic options is discussed.
\end{abstract}

\section{Introduction}

Vitamin D testing has exponentially increased in recent years [1]. The definition and relevance of vitamin D deficiency are still under debate. Recent large observational data have suggested that $\sim 40 \%$ of Europeans are vitamin D deficient, and $13 \%$ are severely deficient [2]. The relevance of this widespread deficiency and necessity for supplementation has been questioned [3]. Certainly, vitamin D is not a panacea. Because more often than not, trials have included non-deficient individuals, it is not surprising that interventional trials have usually not been able to find a benefit of vitamin D supplementation on clinical outcomes. This was also reflected in meta-analyses on the topic that
Karin Amrein

karin.amrein@medunigraz.at

1 Department of Internal Medicine, Division of Endocrinology and Diabetology, Medical University of Graz, Graz, Austria

2 Thyroid Endocrinology Osteoporosis Institute Dobnig, Graz, Austria

3 Executive Department for Quality and Risk Management, University Hospital Graz, Graz, Austria

4 Research Unit for Safety in Health, Division of Plastic, Aesthetic and Reconstructive Surgery, Department of Surgery, Medical University of Graz, Graz, Austria
5 Department of Anaesthesiology and Intensive Care Medicine, Klinikum Klagenfurt am Wörthersee, Klagenfurt am Wörthersee, Austria

6 Immunology and Pathophysiology, Otto Loewi Research Center, Medical University of Graz, Heinrichstrasse 31a, A-8010 Graz, Austria

7 Department of Psychiatry and Psychotherapeutic Medicine, Medical University of Graz, Graz, Austria

8 Department of Anesthesia and Intensive Care, IRCCS-ISMETT (Istituto Mediterraneo per i Trapianti e Terapie ad Alta Specializzazione), Palermo, Italy 
were carried out with poor methodological standards [4]. Consequently, many authors have dismissed a role of vitamin $\mathrm{D}$ on important clinical outcomes, and suggested that vitamin D may be more an associative than a causal factor in acute and chronic disease.

On the other hand, a low vitamin D status is emerging as a very common condition worldwide, and several studies from basic science to clinical applications have highlighted a strong association with chronic diseases, as well as acute conditions. Moreover, the large amount of observational data currently available are also accompanied by pathophysiological associations of vitamin $\mathrm{D}$ with energy homeostasis, and regulation of the immune and endocrine systems [5].

Recent negative interventional trials may be biased by substantial methodological and study design errors, making it impossible to show the potential contributing role of vitamin $\mathrm{D}$ supplementation in a deficient population. Typically, most studies have missed important prerequisites for a nutrient intervention trial: the absence of the problem to be solved-vitamin D deficiency, often ridiculously small sample sizes, and varying interventional regimes regarding dose and metabolite. Even the recent very large trials did not exclusively include deficient populations [6-8]. Moreover, interventional regimes have used a onesize-fits-all approach without taking into account individual differences in BMI and vitamin D metabolism.

\section{Methods}

Articles were individually retrieved up to October 2019 by search in PubMed (MEDLINE). Studies were excluded if they were not in English. Across the last few decades, vitamin D-related research/publications have dramatically increased. Therefore, we decided to focus on the largest, most relevant, and most recent studies that are now in this version of the review.

All authors supplied a first draft paper on a specific topic. All papers were then exchanged and discussed among authors by e-mail.

\section{Definition of vitamin D deficiency}

Serum 25(OH)D is considered to be the best marker for assessing vitamin D status, and reliably reflects the free fractions of the vitamin D metabolites, despite the fact that, in theory, the bioavailable fractions may be more clinically informative [9, 10]. A range of below $75 \mathrm{nmol} / \mathrm{L}$ (or $30 \mathrm{ng} / \mathrm{ml}$ ) of serum/plasma $25(\mathrm{OH}) \mathrm{D}$ concentration is considered vitamin D deficiency by most authors [11, 12]. A cutoff of $<25$ or $<30 \mathrm{nmol} / \mathrm{L}$ (or $10 / 12 \mathrm{ng} / \mathrm{ml}$ ) increases the risk of osteomalacia and nutritional rickets dramatically, and therefore is considered to determine severe vitamin D
Table 1 Risk groups for vitamin D deficiency including high-risk medications.

\begin{tabular}{ll}
\hline Risk group & Medication \\
\hline $\begin{array}{l}\text { Chronic disease, particularly kidney, heart, } \\
\text { and liver failure, in particular transplant }\end{array}$ & $\begin{array}{l}\text { Several antiretroviral } \\
\text { medications }\end{array}$ \\
$\begin{array}{l}\text { candidates and recipients } \\
\text { Gastrointestinal diseases including Crohn's }\end{array}$ & $\begin{array}{l}\text { Antifungals, e.g., } \\
\text { disease, inflammatory bowel disease, and } \\
\text { malabsorption syndromes }\end{array}$ \\
$\begin{array}{ll}\text { Granuloma-forming disorders including } \\
\text { sarcoidosis and tuberculosis }\end{array}$ & $\begin{array}{l}\text { Several antiseizure } \\
\text { medications }\end{array}$ \\
$\begin{array}{l}\text { Hospitalized individuals, especially ICU } \\
\text { patients }\end{array}$ & Cholestyramine \\
$\begin{array}{l}\text { Hyper- and hypoparathyroidism } \\
\text { Obese children and adults, particularly after }\end{array}$ & Rifampicin \\
bariatric surgery & \\
$\begin{array}{l}\text { Older adults with a history of falls and/or } \\
\text { fractures, osteoporosis }\end{array}$ & \\
$\begin{array}{l}\text { Oncologic patients } \\
\text { Pregnant and lactating women, preparing for } \\
\text { pregnancy }\end{array}$ & \\
$\begin{array}{l}\text { Reduced UV-B exposure or effectiveness } \\
\text { (shift workers, immobilized patients, chronic } \\
\text { neuropsychiatric disease, dressing habits, burn } \\
\text { and skin cancer survivors, and nonwhite } \\
\text { persons) }\end{array}$ & \\
Respiratory diseases including COPD, asthma, \\
and cystic fibrosis
\end{tabular}

deficiency [13-16]. The clinical practice guidelines of the Endocrine Society Task Force on Vitamin D [12] have defined a cutoff level of $50 \mathrm{nmol} / \mathrm{L}$ as vitamin $\mathrm{D}$ deficient. Furthermore, different societies and expert bodies have defined $50 \mathrm{nmol} / \mathrm{L}$ as "vitamin $\mathrm{D}$ requirement of nearly all normal healthy persons," by using bone health as the main basis. For example, a cutoff level of $50 \mathrm{nmol} / \mathrm{L}$ is recommended by the Institute of Medicine (IOM, USA) in their "Dietary Reference Intakes". Vitamin D levels of $<30 \mathrm{nmol} /$ $\mathrm{L}$ (or $12 \mathrm{ng} / \mathrm{ml}$ ) should likely be prevented with a public health approach [17]. There are many large and relevant risk groups for vitamin D deficiency (Table 1).

\section{Prevalence of vitamin D deficiency worldwide}

Prevalence rates of severe vitamin D deficiency, defined as $25(\mathrm{OH}) \mathrm{D}<30 \mathrm{nmol} / \mathrm{L}$ (or $12 \mathrm{ng} / \mathrm{ml}$ ), of $5.9 \%$ (US) [18], 7.4\% (Canada) [19], and 13\% (Europe) [2] have been reported. Estimates of the prevalence of $25(\mathrm{OH}) \mathrm{D}$ levels $<50 \mathrm{nmol} / \mathrm{L}$ (or $20 \mathrm{ng} / \mathrm{ml}$ ) have been reported as $24 \%$ (US), $37 \%$ (Canada), and 40\% (Europe) [2, 17-19]. This may vary by age, with lower levels in childhood and the elderly [17], and also ethnicity in different regions, for example, European Caucasians show lower rates of vitamin D deficiency compared with nonwhite individuals [2, 17]. 
Worldwide, many countries report very high prevalences of low vitamin D status. 25(OH)D levels $<30 \mathrm{nmol} / \mathrm{L}$ (or $12 \mathrm{ng} / \mathrm{ml}$ ) in $>20 \%$ of the population are common in India, Tunisia, Pakistan, and Afghanistan. For example, it has been estimated that 490 million individuals are vitamin $\mathrm{D}$ deficient in India [2, 17].

Specific categories of patients have a very high prevalence of vitamin D deficiency. Often, they are characterized by an insufficiency or failure of organs involved in vitamin D metabolism. Patients with chronic renal failure and on hemodialysis, renal transplant recipients affected with liver disease or after liver transplantation may have a prevalence of vitamin D deficiency ranging from 85 to $99 \%$ [20-22].

\section{Vitamin D deficiency in critical illness}

Similarly, critically ill patients have a very high prevalence of vitamin D deficiency, and low vitamin D levels are clearly associated with greater illness severity, morbidity, and mortality in both adult and pediatric intensive care unit (ICU) patients, as well as medical and surgical ICUs [23]. However, as in most other populations, the most important question remains unanswered: whether low vitamin $\mathrm{D}$ is an innocent bystander, simply reflecting greater disease severity, or represents an independent and modifiable risk factor amenable to rapid normalization through loading dose supplementation $[24,25]$.

The question is meaningful, since in this subgroup of patients, many factors contribute to low levels: hemodilution, reduced production and conversion by the liver, reduced synthesis of vitamin D-binding protein, higher consumption during the acute phase of disease and systemic inflammation, and increased tissue demand and enhanced catabolism of metabolites. More data are emerging from basic science about the immediate and late effects of vitamin D supplementation on endocrine, autocrine, and paracrine and genomic targets.

\section{Vitamin D replacement}

\section{Metabolites}

It cannot be emphasized enough that various vitamin $D$ metabolites with a very different efficacy, half-life, and risk of toxicity exist. This is discussed in detail in "Vitamin D supplementation: cholecalciferol, calcifediol and calcitriol" by Reinold Vieth et al. in this special issue.

\section{Interval, target level, and dose}

For some time, bolus dosing was en vogue because it was thought to be interesting for practical reasons. With the exception of critical care, bolus doses with long dosing intervals are not used. They are no longer recommended because of the higher risk of adverse effects (falls and fractures) associated with them [26]. Moreover, the 2017 individual patient data meta-analysis by Martineau et al. showed a clear benefit for vitamin D on acute respiratory infection when daily or weekly dosing was used, but not with longer dosing intervals [16]. In the intensive care, however, a typical daily dose is inefficient, and an upfront loading dose (followed by a daily dose) is necessary to improve vitamin D levels rapidly [27].

It is also important to note that different dosing regimes may have different effects on clinical outcomes. Because a daily dose leads to stable availability of various vitamin $D$ metabolites, this could be an important explanation for many of the negative vitamin D intervention trials [28].

To maintain optimal vitamin D status, use of vitamin D supplementation is often required, as sunlight exposure and dietary intake alone is usually insufficient in most individuals [29-31]. Currently, there is no international consensus on the optimal level for vitamin D supplementation. Recommendations differ in many countries, and range from 400 to 2000 IU daily [11]. A safe and commonly available dose of $25 \mu \mathrm{g}$ of vitamin D3 (1000 IU) raises 25hydroxyvitamin D [25(OH)D] serum level by $15-25 \mathrm{nmol} /$ $\mathrm{L}$ on average (over weeks/months) [32, 33]; it should be noted that there is a nonlinear response of serum $25(\mathrm{OH}) \mathrm{D}$, with a steeper rise with $<1 \mathrm{IU} /$ day of vitamin $\mathrm{D}$, and a more flattened response with $>1$ IU/day. This is evidenced by several studies in all age groups [11,34].

By using the above-mentioned recommended vitamin D supplementation levels, there is no need to monitor serum or urinary calcium or renal function $[35,36]$. There is no international consensus on the safe upper level for vitamin D supplementation. While the upper daily limit given by the Endocrine Society is 10,000 IU [12], the IOM and The European Food and Safety Authority recommend staying below $4000 \mathrm{IU} /$ day $(100 \mu \mathrm{g})[37,38]$. Most countries have prudently set the safe upper level at $50 \mu \mathrm{g}$ daily (2000 IU) for adults [35]. However, this level was set despite the availability of adequate studies of dose-response relationships or toxicity. There is no convincing evidence that daily intakes of up to $125 \mu \mathrm{g}$ (5000 IU) elicit severe adverse effects [39]. It has been reported that an intake of $1250 \mu \mathrm{g}$ (50,000 IU) once every 2 weeks for several years, equivalent to $89.3 \mu \mathrm{g}$ (3571 IU) daily, did not cause hypercalcemia or other evidence of hypervitaminosis D [40]. Small studies showed that even a daily consumption of up to $250 \mu \mathrm{g}$ (10,000 IU) of vitamin D over long periods did not cause adverse effects in healthy adults [32, 33], though some studies revealed a negative impact on bone mineral density by using high-dose vitamin $\mathrm{D}$ supplementation of 10,000 IU/day [11]. Nevertheless, supplementation of 
$>10,000 \mathrm{IU}$ of vitamin D is rarely necessary in clinical practice.

As there is no evidence that increasing the recommended daily dose of vitamin $\mathrm{D}$ supplementation up to $50 \mu \mathrm{g}$ (2000 IU) would cause severe side effects in the general population, and considering that $20 \mu \mathrm{g}$ (800 IU) is the lowest dose consistently associated with a bone benefit, it seems reasonable to recommend a daily dose of $20-50 \mu \mathrm{g}$ (800-2000 IU) (levels 2-4 evidence, grades B-D recommendation) [39]. In general, a daily vitamin $\mathrm{D}$ of $800 \mathrm{IU}$ appears to be sufficient to achieve a target 25(OH)D level of at least $50 \mathrm{nmol} / \mathrm{L}$ (or $20 \mathrm{ng} / \mathrm{mL}$ ) in most healthy individuals, whereas $2000 \mathrm{IU}$ is sufficient to achieve a level of at least $75 \mathrm{nmol} / \mathrm{L}$ (or $30 \mathrm{ng} / \mathrm{mL}$ ).

Some data suggest that a higher $25(\mathrm{OH}) \mathrm{D}$ level than $50 \mathrm{nmol} / \mathrm{L}$ (or $20 \mathrm{ng} / \mathrm{mL}$ ) may be required for optimal risk reduction for various endpoints [41-44].

\section{Toxicity}

The use of vitamin D supplementation has increased substantially. Growing awareness of vitamin D in the general population, and over-the-counter vitamin $\mathrm{D}$ with partially very high doses, include the risk for uncontrolled use and exogenous hypervitaminosis $\mathrm{D}$, resulting in high concentrations of serum $25(\mathrm{OH}) \mathrm{D}$ or free 1,25-dihydroxyvitamin $\mathrm{D}\left[1,25(\mathrm{OH})_{2} \mathrm{D}\right]$, leading to hypercalciuria and finally hypercalcemia [45]. Reports of vitamin D overdose are rare in the literature. Serum $25(\mathrm{OH}) \mathrm{D}$ usually exceeds $375 \mathrm{nmol} / \mathrm{l}$ (or $150 \mathrm{ng} / \mathrm{ml}$ ), and factors such as high-calcium intake contribute to the risk of hypercalcemia [46]. However, there are also endogenous causes of hypervitaminosis $\mathrm{D}$, such as increased production of $1,25(\mathrm{OH})_{2} \mathrm{D}$ as part of granulomatous disorders or lymphomas [47]. Having a long half-life in the tissues, vitamin $\mathrm{D}$ accumulation due to excessive intake lasts up to 18 months [48], and may cause chronic toxic effects such as nephrocalcinosis following hypercalcemia and hypercalciuria [47].

Since the 1930s, public health officials in the United States and the United Kingdom have recommended routine fortification of foods like milk to prevent vitamin D deficiency and low vitamin D status, which was expected to be an effective public health strategy [46]. However, there was an increased incidence of hypercalcemia due to massive intakes of vitamin D from various food fortifications. In some cases, hypercalcemia was associated with drinking vitamin D-fortified milk, revealing a fortification of up to $232,565 \mathrm{IU}$ instead of standard $400 \mathrm{IU} / q u a r t$, and consequently, prohibition of milk fortification [49]. However, current evidence suggests that vitamin D fortification prevents deficiency safely and effectively [50, 51]. Feeding animals might represent an additional source of vitamin D without compromising product quality. For example, consumption of vitamin D-enriched eggs from hens fed with additional vitamin D3 resulted in a zero prevalence $<25 \mathrm{nmol} / \mathrm{L}$, while the control group showed an usual seasonal decline in winter with $22 \%$ being $<25 \mathrm{nmol} / \mathrm{L}$ [52]. The rationale and guidance for systematic vitamin $\mathrm{D}$ food fortification, including a call for action, has recently been published by an expert group of vitamin D scientists.

\section{Selected RCTs in recent years}

Several very large randomized controlled trials have been or are being performed in recent years. They are summarized in Table 2 [53-63].

\section{Effect size and basic statistical principles}

Though it appears attractive to dismiss any relevant effect of vitamin $\mathrm{D}$ on all the conditions that have been studied in those partly very large trials in recent years, it must be considered that often the basic principles for optimal design of a nutrient intervention study were not fulfilled [64], e.g., measurement of vitamin $\mathrm{D}$ at baseline and choosing vitamin $\mathrm{D}$ deficiency as an inclusion criterion, using a meaningful intervention able to change vitamin $\mathrm{D}$ status, and verification of vitamin $\mathrm{D}$ status improvement by repeat measurement.

Moreover, even in the largest trials including thousands of individuals, the sample size was still too small when mostly individuals without vitamin D deficiency and a low baseline risk were included. By modeling future intervention trials, Brenner et al. reported that several hundreds of thousands of participants would be necessary to be able to show an effect on mortality [65].

On the other hand, even a very small effect may be useful for a substance with such an excellent safety profile and low cost, especially when considering a public health approach. However, to show a small, but meaningful benefit on important outcomes like mortality or infections, very large population samples are needed, but such trials are very costly and will likely be scant.

\section{Important systematic reviews and meta- analyses}

The association of vitamin D supplementation on a number of endpoints including mortality has been explored in more detail in the last few years. Selected relevant systematic reviews and meta-analyses are summarized in Table 3 $[16,66,67]$. 


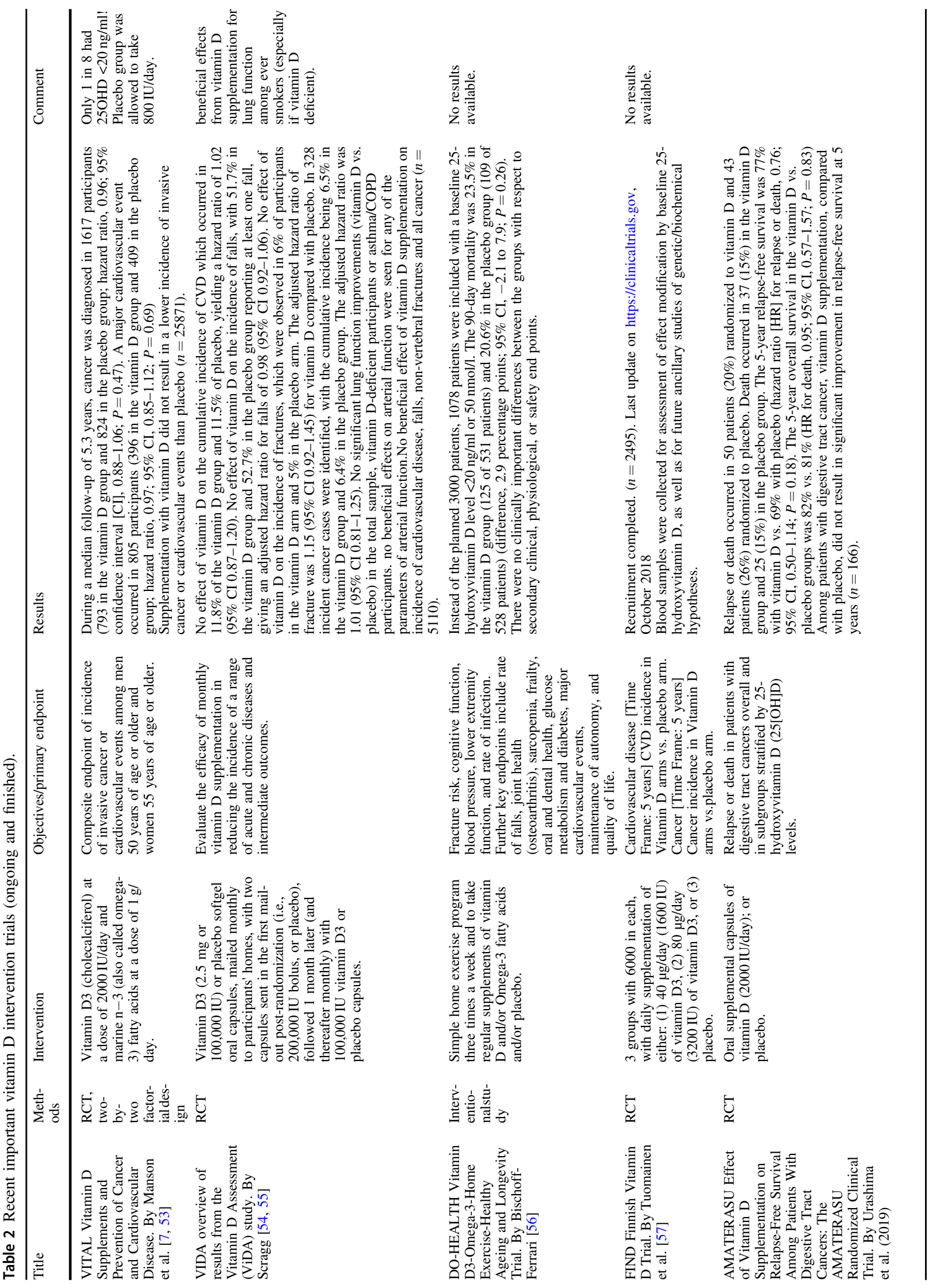




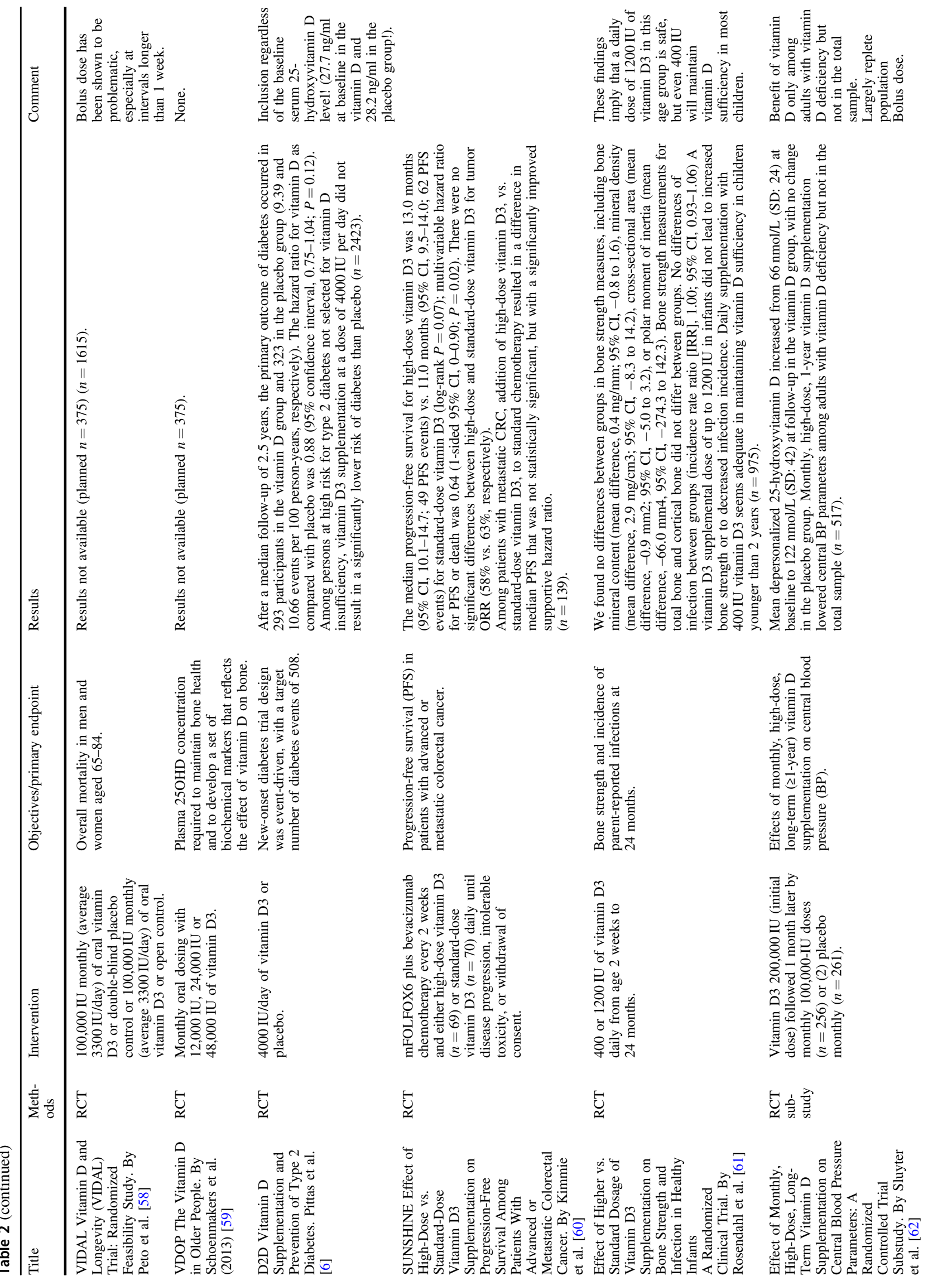




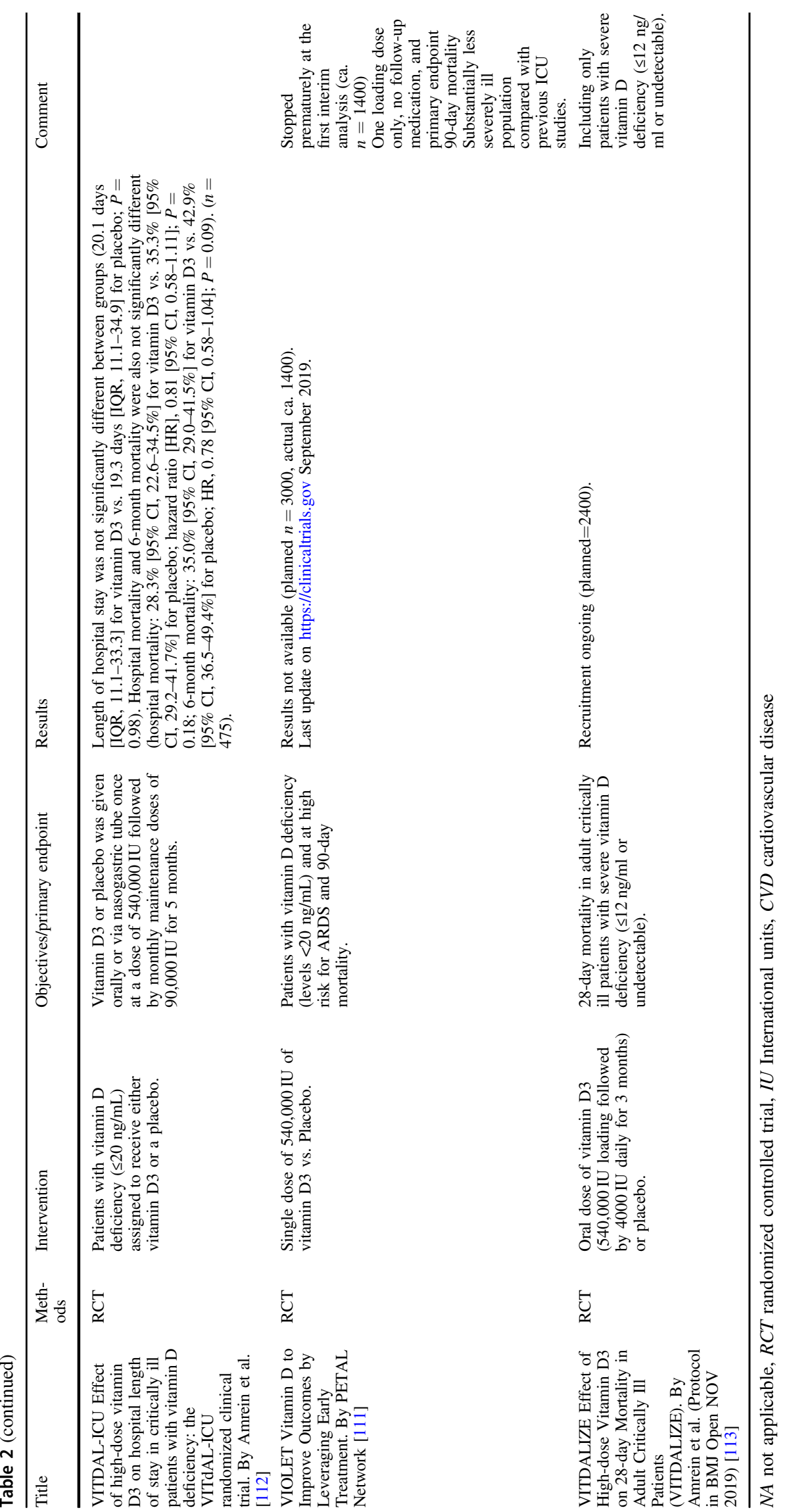




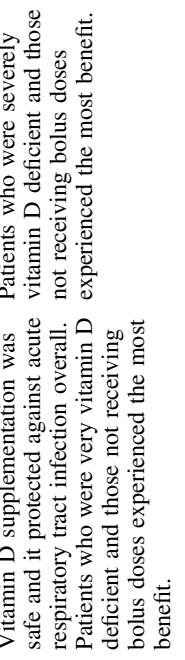

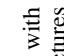

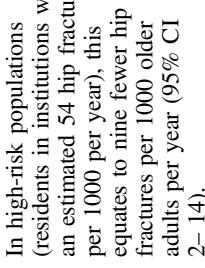

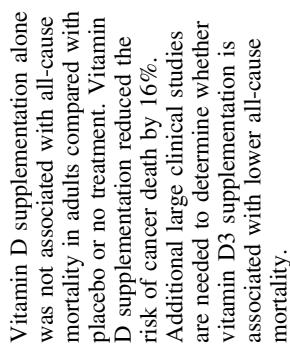

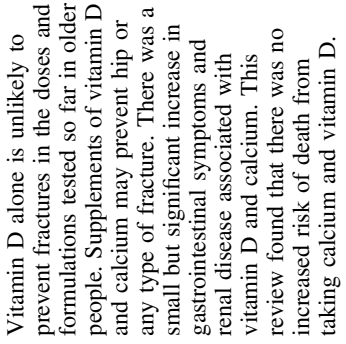

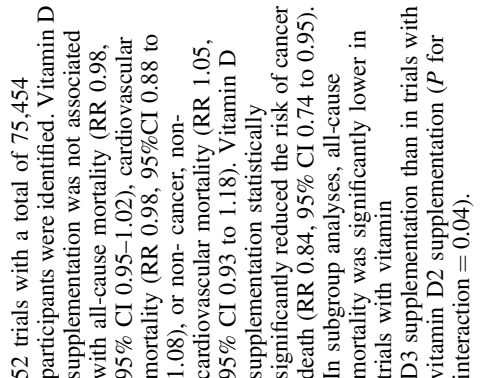

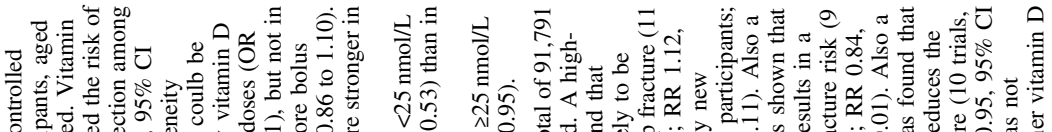

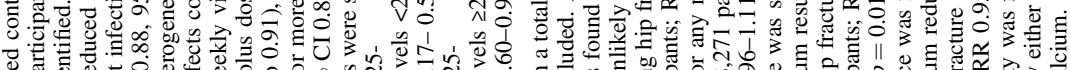

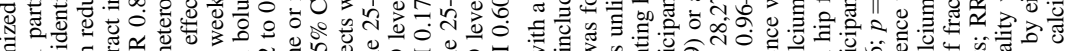

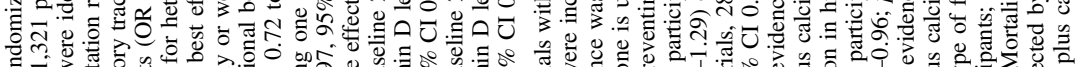

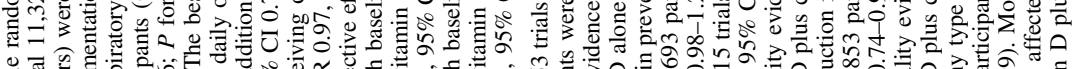

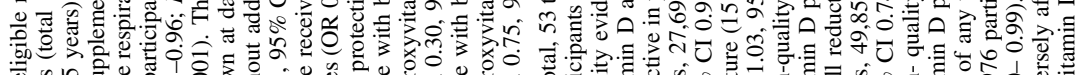

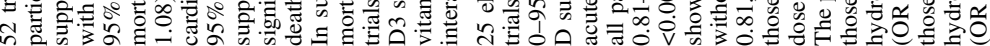

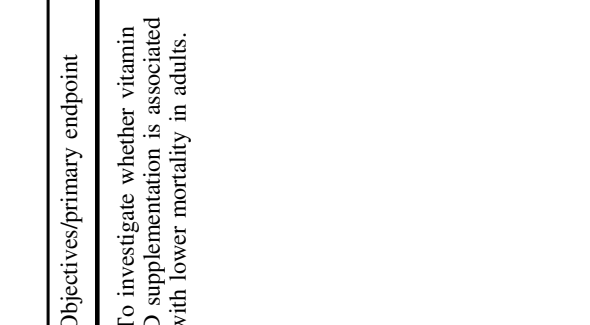

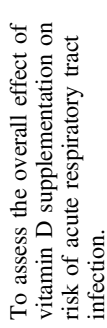

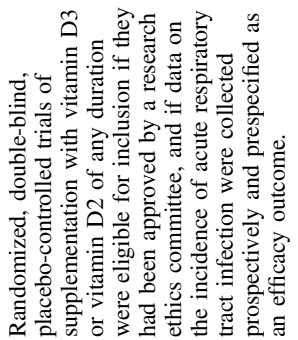

竞

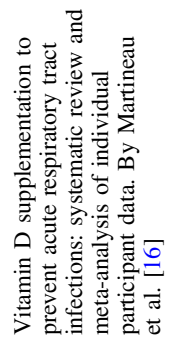

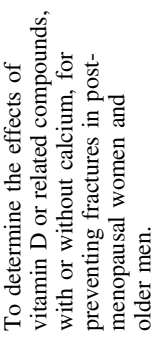

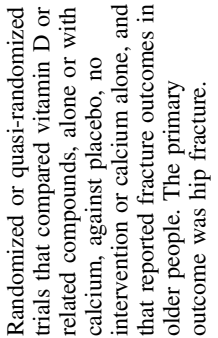

?

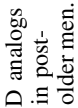

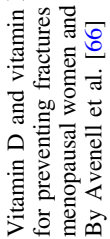




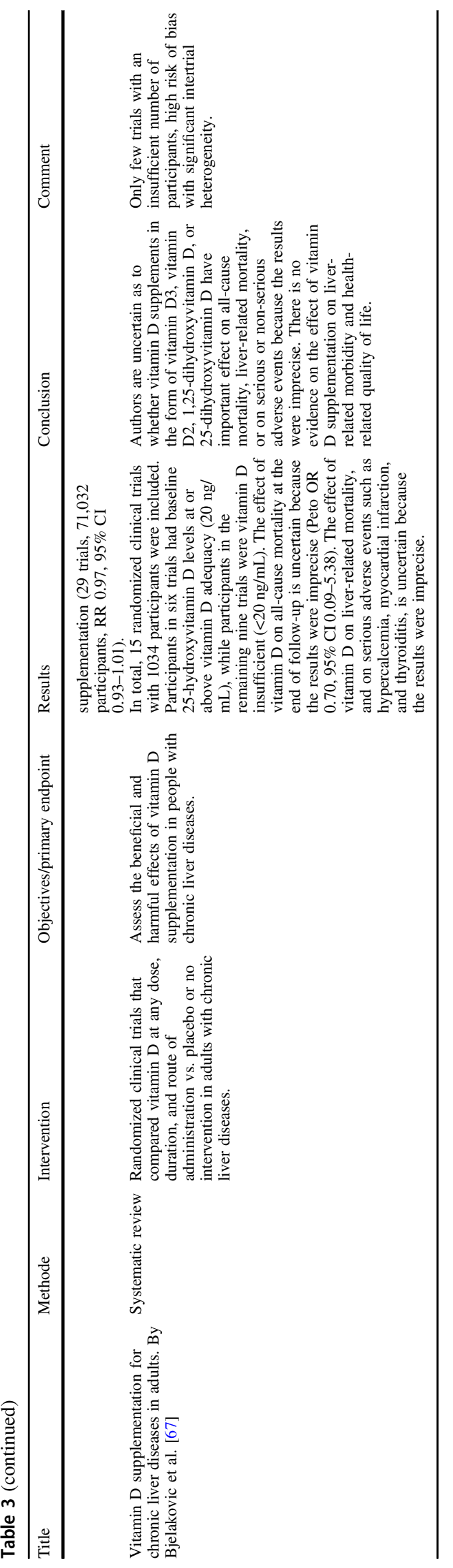

Selected target organs, conditions, and
endpoints

Mortality

Vitamin D deficiency has been strongly associated with various health outcomes, including all-cause mortality [68]. A 2014 Cochrane meta-analysis showed a relevant and significant lower all-cause mortality of $\sim 7 \%$ and cancer mortality of $\sim 13 \%$ in patients who received vitamin D3 [69]. The results of a meta-analysis by using individual participant data conducted by Gaksch et al., analyzing almost 17,000 individuals, showed a strong association between low 25(OH)D and increased risk of all-cause mortality [70]. Using a Mendelian randomization with genetic variants in the vitamin D synthesis pathway, the analysis of Aspelund et al. supports a causal relationship between vitamin $\mathrm{D}$ deficiency and increased all-cause mortality. However, despite a cohort of $>10,000$ participants, it was still too underpowered to confirm a causal relationship [71].

\section{Lung}

The effect of vitamin D on the lungs has a strong rationale, demonstrated by basic science, due to its immunomodulant, anti-inflammatory, and anti-infective role that has been highlighted in patients with community-acquired infections, acute respiratory failure, as well as in lung transplantation recipients (this is a very specific model for severe infective and inflammatory lung disease) [21].

Vitamin D supplementation reveals direct antiinflammatory properties in the lungs. This is due to local inhibition of nuclear factor- $\mathrm{kB}$ and mitogen-activated protein kinase activity, reducing the secretion of inflammatory cytokines and chemokines involved in the lung inflammatory process and extravascular leaking, such as interleukin (IL)-1 $\beta$, IL-6, and IL-8. This, in turn, also influences the number of inflammatory cells infiltrating the interstitial space [72]. Moreover, $1,25(\mathrm{OH})_{2} \mathrm{D}$ is also implicated in the reduction of oxidative stress by inhibiting anti-protease activity, and acting on the nuclear factor erythroid-related factor 2, a transcriptional regulator of most antioxidant genes. Moreover, vitamin D acts with well-known antiinfectious properties by increasing proliferation of monocytes to macrophages (acting as a fine-tuner of the innate and adaptive immunity), and determining a transcriptional upregulation of cathelicidin also in the airway epithelial cells. Finally, $1,25(\mathrm{OH})_{2} \mathrm{D}$ inhibits the expression of several metalloproteinases in airway smooth-muscle cells and alveolar macrophages, thus being involved in the tissue remodeling pathway by regulating the process of bronchial airway muscle activation and extracellular matrix deposition 
by fibroblasts. All these complex pathways, partially modified by vitamin $\mathrm{D}$, warrant supplementation in patients with respiratory disease. Significant benefits have already been shown in adults and children with asthma, and for the prevention of respiratory tract infections, particularly in severe vitamin D deficiency.

\section{Sepsis}

Sepsis, a complication of severe infection, is characterized by signs of systemic inflammation expressed with failure of organs often remote from the site of the initial infection. Septic patients have high mortality and lower circulating levels of vitamin D. The interest in vitamin D for infection has risen after the recognition of the expression of the vitamin $\mathrm{D}$ receptor, ubiquitous in cells of the innate and adaptive immune system. Vitamin D is an important link between Toll-like receptor activation and antibacterial responses. The in vivo supplementation of a high dose of cholecalciferol (400.000 IU as a single bolus) in the early stage of sepsis and septic shock has been shown able to safely and rapidly increase the level of vitamin D, as well as the circulating level of cathelicidin, a vitamin D-dependent endogenous anti-microbial and endotoxin-binding peptide largely found in human neutrophils [73]. These findings were corroborated by the significant reduction of IL-1 $\beta$ and IL-6, which play important roles in the early inflammatory response.

\section{Organ transplantation recipients}

Several studies have highlighted that lower 25(OH)D levels are associated with prolonged hospitalization and mortality, also in the postsurgical setting. Given its wide immunobiological effects, vitamin $\mathrm{D}$ has been frequently considered a potential modulating factor after solid organ (and stem cell) transplantation (mainly liver, kidney, and lung). The transplantation recipient population is particularly prone to infections, mainly in the early stage after transplantation, due to immunomodulation/chronic immunosuppressive therapy and to long-term bone dysfunction. The recipients of solid organ transplantation are, by definition, vitamin D insufficient for manifold reasons, including limited sunlight exposure, limited physical activity, reduced dietary intake of vitamin D in food, as well as liver and kidney dysfunction according to their main disease. As an example, in liver transplantation recipients (a group of patients with very low vitamin D levels), osteoporosis has a high prevalence, with a large decline in bone mineral density in the first year after transplantation. Moreover, a negative association between low vitamin D levels and graft function, as well as a role of vitamin $\mathrm{D}$ in reducing the recurrence of hepatitis $\mathrm{C}$ virus infection, has been demonstrated. Several interventional trials on vitamin D supplementation in lung and kidney recipients are ongoing under the hypothesis that vitamin $\mathrm{D}$ supplementation may contribute to reducing the occurrence of rejection by it immunomodulating action.

\section{Pregnancy}

In 2019, two Cochrane analyses on vitamin D and pregnancy were published. They suggested that vitamin D supplementation may reduce gestational diabetes, low birthweight, and preeclampsia, but a higher than currently recommended dose appeared to have no additional benefit except for possible further reduction of gestational diabetes [74, 75]. However, several studies in recent years have highlighted that women are at high risk for vitamin D deficiency, and this is associated with adverse pregnancy outcomes, including preeclampsia and gestational diabetes [76-80]. It has been demonstrated that vitamin D supplementation is able to reduce adverse pregnancy outcomes when a higher level is achieved, with an increasing efficacy when the target level is raised from 20 to $40 \mathrm{ng} / \mathrm{mL}$ or $50 \mathrm{ng} / \mathrm{mL}$. Interestingly, the maximum change is achieved 6-8 weeks after initiating the treatment, likely exerting the genomic actions of vitamin D [81-83]. Three major adverse pregnancy outcomes appear to improve with vitamin D supplementation: a $60 \%$ reduction in preeclampsia, a $50 \%$ reduction in gestational diabetes, and a $40 \%$ reduction in preterm delivery [84]. These data are consistent with previous work on the topic [82]. Moreover, following the genomic and epigenetic effects of vitamin D supplementation, vitamin D deficiency during pregnancy also seems able to induce specific genomic pathways relevant to autoimmune disease in childhood and later in life [85, 86]. The placenta can convert $25(\mathrm{OH}) \mathrm{D}$ to the active form $1,25(\mathrm{OH})$ ${ }_{2} \mathrm{D}$, similarly to the kidneys; therefore, more basic research should shed light in the future on the specific vitamin D metabolism during pregnancy [85]. The FDA has recently approved the statement "Pregnant women who have higher serum vitamin D levels have a decreased risk of preterm birth."

Taking into account the recent literature, vitamin D deficiency is associated with worse outcomes during pregnancy, and at least 400-600 IU of daily vitamin D supplementation is reasonable for women with a vitamin $\mathrm{D}$ level $<40 \mathrm{ng} / \mathrm{mL}$, with higher required doses in more severe deficiency.

\section{Cancer}

Vitamin D supplementation as a strategy for preventing cancer was considered, as results from several observational studies suggested an association between vitamin D deficiency and risk for several types of cancer [87]. It was 
already assumed in 1980 that calcitriol could inhibit the growth of malignant melanoma cells [88]. Ecologic studies revealed a decreased cancer mortality in areas with greater sun exposure [11]. Over the decades, vitamin D and its anticancer action was investigated for various malignancies resulting in mixed findings [89]. Hence, the cancerprotective effect of vitamin D remained unclear. In 2014, two meta-analyses revealed no significant decrease in the incidence of cancer in association with vitamin D supplementation, but a significant reduction in the rate of death from cancer [90, 91]. However, as most of the data derive from observational studies, correlation does not imply causation. Investigating cancer incidence following vitamin $\mathrm{D}$ plus calcium supplementation, Lappe et al. revealed a non-, but nearly significant (hazard ratio $0.70 ; 95 \%$ CI 0.47-1.02) 30\% risk reduction compared with placebo [92]. A recent large RCT using a daily dose of 2000 IU vitamin D3 conducted by Manson et al. [7], analyzing the incidence of cancer following vitamin D supplementation in over 25,000 participants, did not reveal a significant reduction neither of invasive cancer of any type nor in the rate of death from any cause. However, subgroup analyses revealed a significant lower cancer incidence in normalweight individuals. Considering that the study was not adjusted for this comparison, this finding should be considered hypothesis-generating. An ongoing long-term RCT [93], investigating vitamin D supplementation and the incidence of cancer and precancerous lesions in a high-risk population (overweight adults with prediabetes), will provide further and important data on the causality.

\section{Diabetes}

Several studies demonstrated a link between 25(OH)D levels and diabetes, and revealed a higher frequency of vitamin D deficiency in patients with type 1 diabetes mellitus (T1DM) compared with healthy individuals [94-97]. Investigating prenatal vitamin $\mathrm{D}$ exposure of the fetus, a lower gestational 25(OH)D level [98] or avoiding vitamin D-fortified food [99] was significantly associated with higher risk of developing T1DM. In infancy, vitamin D supplementation [100] or vitamin D-fortified margarine [99] was shown to reduce the risk of developing type 1 diabetes mellitus. The effect of vitamin D supplementation on T1DM onset seems to be dependent on life stage. Supplementation between 7 and 12 months of age resulted in an almost twofold lower risk of developing T1DM compared with earlier supplementation [101]. In adolescents, many studies revealed no association between $25(\mathrm{OH}) \mathrm{D}$ level and onset of T1DM [102-104]. However, there is a clear effect of vitamin $\mathrm{D}$ in young adults, as low $25(\mathrm{OH}) \mathrm{D}$ levels were significantly associated with developing T1DM [105]. However, according to the available literature, the cause- and-effect relationship is inconclusive. On the other hand, diabetes per se results in physiological changes too, such as increased renal elimination of vitamin D-binding protein compared with healthy individuals [106]. Therefore, the value of hypovitaminosis D as a trigger for developing T1DM remains unclear. Vitamin D deficiency was also shown to have a negative impact on insulin resistance [107]. Hence, a higher risk of developing type 2 diabetes mellitus (T2DM) in individuals with low $25(\mathrm{OH}) \mathrm{D}$ levels was assumed. However, vitamin D supplementation did overall not result in a lower risk of developing T2DM [6, 108]. In the recent D2D study by Pittas et al., vitamin D did not significantly reduce new onset of diabetes, but vitamin D deficiency was no inclusion criterion, and only a minority of included patients had a $25(\mathrm{OH}) \mathrm{D}$ level $<50 \mathrm{nmol} / / \mathrm{L}$ (or $20 \mathrm{ng} / \mathrm{mL}$ ). Moreover, the hypothesized treatment effect used for the sample size calculation was relatively large (hazard ratio 0.75 for the vitamin $\mathrm{D}$ group). The actual hazard ratio for vitamin $\mathrm{D}$ as compared with placebo was 0.88 (95\% confidence interval, 0.75-1.04; $P=0.12$ ). Interestingly, the effect appeared to be stronger in patients with a BMI <30. However, a post hoc subgroup analysis of individuals with a 25(OH)D level below $12 \mathrm{ng} / \mathrm{ml}(30 \mathrm{nmol} /$ 1) revealed a significantly reduced risk of developing T2DM (hazard ratio $0.38 ; 95 \% \mathrm{CI}, 0.18-0.80$ ).

\section{Musculoskeletal effects of vitamin D}

The detrimental effects of vitamin D deficiency on the musculoskeletal system were the first visible mode of action that was attributed to vitamin D (i.e., rickets in children).

The necessity of an adequate vitamin D status for muscle and bone health is undebated, and therefore not discussed in detail in this review.

\section{Vitamin D intoxication and hypersensitivity}

Vitamin D intoxication is rare and usually only occurs at very high supplementation doses [109]. However, various mutations in vitamin D metabolizing enzymes that may lead to increased sensitivity to standard vitamin D supplementation or even endogenous vitamin $\mathrm{D}$ intoxication with hypercalcemia, hypercalciuria, and nephrocalcinosis/ chronic renal insufficiency have been described [110]. Typically, these mutations affect CYP24A1, the enzyme that catabolizes $1,25 \mathrm{OHD} 2$ to the inactive metabolite $24,250 H D 2$. Therefore, a diagnosis can be made by using the ratio of 24,25:25 D and does not necessarily require genetic testing.

This condition has been termed idiopathic infantile hypercalcemia, but due to the greatly varying clinical phenotypes, patients may well become symptomatic only in 
adulthood. Currently, no causal treatment is available, but avoidance of a high-calcium diet, UV-B exposure, and vitamin $\mathrm{D}$ or calcium supplements is advised.

\section{The future}

Vitamin D deficiency is highly prevalent, but the literature to support vitamin D supplementation is unsatisfactory to date. Unless major funding sources are used for vitamin D research, it appears sensible to focus on vitamin D-deficient populations with a high event rate. Vitamin D is clearly not a panacea, but may be an important, inexpensive, and safe adjuvant therapy for many diseases and stages of life, including pregnancy, childhood, and old age. Public health efforts to prevent severe vitamin D deficiency should therefore be further promoted.

In the critically ill setting, one large vitamin D supplementation trial has recently been published (VIOLET [111]) and one is still ongoing (NCT03096314 and NCT03188796). VIOLET randomized patients with 25 (OH)D levels below $50 \mathrm{nmol} / \mathrm{L}$ (or $20 \mathrm{ng} / \mathrm{ml}$ ) "at risk for ARDS" to one single high dose of vitamin D3 (540,000 IU), and evaluated its effect on the primary outcome: 90-day mortality. It was prematurely stopped in mid-2018 after inclusion of ca. One-third of the patients originally planned, and no differences in mortality and secondary endpoints have been reported, with no differences in subgroup analyses and safety endpoints [111].

VITDALIZE is a European multicenter RCT, including severely vitamin D-deficient ICU patients with a $25 \mathrm{OH} \mathrm{D}$ level $<30 \mathrm{nmol} / \mathrm{L}$ (or $12 \mathrm{ng} / \mathrm{ml}$ ), and randomizes patients to a loading dose of oral/enteral vitamin D3 (540,000 IU) followed by $4000 \mathrm{IU}$ daily for 90 days, with the primary outcome being 28-day mortality. Recruitment is ongoing in Austria and Belgium, should be expanded to other European countries in 2020, and will likely continue for a few more years.

\section{Compliance with ethical standards}

Conflict of interest KA has received speaker honoraria and an unrestricted grant from Fresenius Kabi. The other authors declare that they have no conflict of interest.

Publisher's note Springer Nature remains neutral with regard to jurisdictional claims in published maps and institutional affiliations.

\section{References}

1. Crowe FL, Jolly K, MacArthur C, Manaseki-Holland S, Gittoes $\mathrm{N}$, Hewison $\mathrm{M}$, et al. Trends in the incidence of testing for vitamin $\mathrm{D}$ deficiency in primary care in the UK: a retrospective analysis of The Health Improvement Network (THIN), 2005-2015. BMJ Open. 2019;9:e028355. https://doi.org/10. 1136/bmjopen-2018-028355

2. Cashman KD, Dowling KG, Škrabáková Z, Gonzalez-Gross M, Valtueña J, De Henauw S, et al. Vitamin D deficiency in Europe: pandemic? Am J Clin Nutr. 2016;103:1033-44. https://doi.org/ 10.3945/ajen.115.120873

3. Zhang Y, Fang F, Tang J, Jia L, Feng Y, Xu P, et al. Association between vitamin D supplementation and mortality: systematic review and meta-analysis. BMJ. 2019;366:14673. https://doi.org/ 10.1136/bmj.14673

4. Amrein K, Martucci G, McNally JD. When not to use metaanalysis: analysing the meta-analyses on vitamin $\mathrm{D}$ in critical care. Clin Nutr. 2017;36:1729-30. https://doi.org/10.1016/j.clnu. 2017.08.009.

5. Bouillon R, Carmeliet G, Lieben L, Watanabe M, Perino A, Auwerx J. et al. Vitamin D and energy homeostasis: of mice and men. Nat Rev Endocrinol. 2014;10:79-87. https://doi.org/10. 1038/nrendo.2013.226.

6. Pittas AG, Dawson-Hughes B, Sheehan P, Ware JH, Knowler WC, Aroda VR, et al. Vitamin D supplementation and prevention of type 2 diabetes. N. Engl J Med. 2019;381:520-30. https:// doi.org/10.1056/NEJMoa1900906

7. Manson JE, Cook NR, Lee I-M, Christen W, Bassuk SS, Mora S, et al. Vitamin D supplements and prevention of cancer and cardiovascular disease. N Engl J Med. 2018;380:33-44. https:// doi.org/10.1056/NEJMoa1809944

8. Grant WB, Boucher BJ. Why secondary analyses in vitamin d clinical trials are important and how to improve vitamin d clinical trial outcome analyses - a comment on "Extra-Skeletal Effects of Vitamin D, Nutrients 2019, 11, 1460". Nutrients. 2019;11:2182.

9. Martucci G, Tuzzolino F, Arcadipane A, Pieber TR, Schnedl C, Urbanic Purkart T. et al. The effect of high-dose cholecalciferol on bioavailable vitamin D levels in critically ill patients: a post hoc analysis of the VITdAL-ICU trial. Intensiv Care Med. 2017;43:1732-4. https://doi.org/10.1007/s00134-017-4846-5.

10. De Pascale G, Quraishi SA. Vitamin D status in critically ill patients: the evidence is now bioavailable!. Crit Care. 2014;18:449. https://doi.org/10.1186/cc13975.

11. Institute of Medicine. Dietary reference intakes for calcium and vitamin D. Washington, DC: The National Academies Press; 2011.

12. Holick MF, Binkley NC, Bischoff-Ferrari HA, Gordon CM, Hanley DA, Heaney RP, et al. Evaluation, treatment, and prevention of vitamin D deficiency: an Endocrine Society Clinical Practice Guideline. J Clin Endocrinol Metab. 2011;96:1911-30. https://doi.org/10.1210/jc.2011-0385

13. EFSA Panel on Dietetic Products N, Allergies. Dietary reference values for vitamin D. EFSA J. 2016;14:e04547. https://doi.org/ 10.2903/j.efsa.2016.4547

14. Braegger C, Campoy C, Colomb V, Decsi T, Domellof M, Fewtrell M, et al. Vitamin D in the healthy european paediatric population. J Pediatr Gastroenterol Nutr. 2013;56:692-701. https://doi.org/10.1097/MPG.0b013e31828f3c05

15. Munns CF, Shaw N, Kiely M, Specker BL, Thacher TD, Ozono $\mathrm{K}$, et al. Global consensus recommendations on prevention and management of nutritional rickets. J Clin Endocrinol Metab. 2016;101:394-415. https://doi.org/10.1210/jc.2015-2175

16. Martineau AR, Jolliffe DA, Hooper RL, Greenberg L, Aloia JF, Bergman P, et al. Vitamin D supplementation to prevent acute respiratory tract infections: systematic review and meta-analysis of individual participant data. BMJ. 2017;356:i6583. https://doi. org/10.1136/bmj.i6583

17. Cashman KD. Vitamin D deficiency: defining, prevalence, causes, and strategies of addressing. Calcif Tissue Int. 2019. https:// doi.org/10.1007/s00223-019-00559-4 
18. Schleicher RL, Sternberg MR, Looker AC, Yetley EA, Lacher DA, Sempos CT, et al. National estimates of serum total 25Hydroxyvitamin D and metabolite concentrations measured by liquid chromatography-Tandem mass spectrometry in the US population during 2007-2010. J Nutr. 2016;146:1051-61. https://doi.org/10.3945/jn.115.227728

19. Sarafin K, Durazo-Arvizu R, Tian L, Phinney KW, Tai S, Camara JE, et al. Standardizing 25-hydroxyvitamin D values from the Canadian Health Measures Survey. Am J Clin Nutr. 2015;102:1044-50. https://doi.org/10.3945/ajcn.114.103689

20. Courbebaisse M, Alberti C, Colas S, Prie D, Souberbielle JC, Treluyer JM. et al. Vitamin D supplementation in renAL transplant recipients (VITALE): a prospective, multicentre, doubleblind, randomized trial of vitamin D estimating the benefit and safety of vitamin D3 treatment at a dose of 100,000 UI compared with a dose of 12,000 UI in renal transplant recipients: study protocol for a double-blind, randomized, controlled trial. Trials. 2014;15:430. https://doi.org/10.1186/1745-6215-15-430.

21. Vos R, Ruttens D, Verleden SE, Vandermeulen E, Bellon H, Van Herck A, et al. High-dose vitamin D after lung transplantation: a randomized trial. J Heart Lung Transplant. 2017;36:897-905. https://doi.org/10.1016/j.healun.2017.03.008.

22. Zhou Q, Li L, Chen Y, Zhang J, Zhong L, Peng Z, et al. Vitamin D supplementation could reduce the risk of acute cellular rejection and infection in vitamin $\mathrm{D}$ deficient liver allograft recipients. Int Immunopharmacol. 2019;75:105811 https://doi. org/10.1016/j.intimp.2019.105811.

23. Cariolou M, Cupp MA. Importance of vitamin D in acute and critically ill children with subgroup analyses of sepsis and respiratory tract infections: a systematic review and metaanalysis. Crit care (Lond, Engl). 2019;9:e027666. 10.1136/ bmjopen-2018-027666.

24. Lee P, Nair P, Eisman JA, Center JR. Vitamin D deficiency in the intensive care unit: an invisible accomplice to morbidity and mortality? Intensive care Med. 2009;35:2028-32. https://doi.org/ 10.1007/s00134-009-1642-x.

25. Martucci G, McNally D, Parekh D, Zajic P, Tuzzolino F, Arcadipane A. et al. Trying identify who may benefit most future Vitam D intervention trials: a post hoc Anal VITDAL-ICU study excluding early deaths. Crit Care. 2019;23:200. https://doi.org/ 10.1186/s13054-019-2472-z.

26. Sanders KM, Stuart AL, Williamson EJ, Simpson JA, Kotowicz MA, Young D, et al. Annual High-dose oral vitamin D and falls and fractures in older women: a randomized controlled trial. JAMA. 2010;303:1815-22. https://doi.org/10.1001/jama.2010.594

27. Amrein K, Papinutti A, Mathew E, Vila G, Parekh D. Vitamin D and critical illness: what endocrinology can learn from intensive care and vice versa. Endocr Connect. 2018;7:R304-R315. https://doi.org/10.1530/EC-18-0184

28. Hollis BW, Wagner CL. The role of the parent compound vitamin $\mathrm{D}$ with respect to metabolism and function: why clinical dose intervals can affect clinical outcomes. J Clin Endocrinol Metab. 2013;98:4619-28. https://doi.org/10.1210/ jc. 2013-2653

29. Roth DE, Martz P, Yeo R, Prosser C, Bell M, Jones AB. Are national vitamin $\mathrm{D}$ guidelines sufficient to maintain adequate blood levels in children? Can J Public Health. 2005;96:443-9. epub ahead of print 2005/12/15.

30. Rucker D, Allan JA, Fick GH, Hanley DA. Vitamin D insufficiency in a population of healthy western Canadians. CMAJ. 2002;166:1517-24.

31. Vieth R, Cole DE, Hawker GA, Trang HM, Rubin LA. Winter time vitamin D insufficiency is common in young Canadian women, and their vitamin D intake does not prevent it. Eur $\mathrm{J}$ Clin Nutr. 2001;55:1091-7. https://doi.org/10.1038/sj.ejen. 1601275.
32. Heaney RP, Davies KM, Chen TC, Holick MF, Barger-Lux MJ. Human serum 25-hydroxycholecalciferol response to extended oral dosing with cholecalciferol. Am J Clin Nutr. 2003;77:204-10. https://doi.org/10.1093/ajcn/77.1.204.

33. Hathcock JN, Shao A, Vieth R, Heaney R. Risk assessment for vitamin D. Am J Clin Nutr. 2007;85:6-18. https://doi.org/10. 1093/ajen/85.1.6

34. Pfeifer M, Begerow B, Minne HW, Abrams C, Nachtigall D, Hansen C. Effects of a short-term vitamin D and calcium supplementation on body sway and secondary hyperparathyroidism in elderly women. J Bone Miner Res. 2000;15:1113-8. https:// doi.org/10.1359/jbmr.2000.15.6.1113

35. Medicine Io. Dietary reference intakes for calcium, phosphorus, magnesium, vitamin D, and fluoride. The Washington, DC: National Academies Press; 1997.

36. Aloia JF, Patel M, DiMaano R, Li-Ng M, Talwar SA, Mikhail $\mathrm{M}$, et al. Vitamin D intake to attain a desired serum 25hydroxyvitamin D concentration. Am J Clin Nutr. 2008;87:1952-8. https://doi.org/10.1093/ajcn/87.6.1952

37. Ross AC, Manson JE, Abrams SA, Aloia JF, Brannon PM, Clinton SK, et al. The 2011 report on dietary reference intakes for calcium and vitamin D from the institute of medicine: what clinicians need to know. J Clin Endocrinol Metab. 2011;96:53-58. https://doi.org/10.1210/jc.2010-2704

38. EFSA Panel on Dietetic Products N, Allergies. Scientific opinion on the tolerable upper intake level of vitamin D. EFSA J. 2012;10:2813. https://doi.org/10.2903/j.efsa.2012.2813

39. Hanley DA, Cranney A, Jones G, Whiting SJ, Leslie WD, Cole DEC, et al. Vitamin D in adult health and disease: a review and guideline statement from Osteoporosis Canada. CMAJ. 2010;182:E610-E618. https://doi.org/10.1503/cmaj.080663. epub ahead of print 2010/07/12

40. Pietras SM, Obayan BK, Cai MH, Holick MF. Vitamin D2 treatment for vitamin D deficiency and insufficiency for up to 6 Years. JAMA Intern Med. 2009;169:1806-18. https://doi.org/10. 1001/archinternmed.2009.361

41. McDonnell SL, Baggerly CA, French CB, Baggerly LL, Garland $\mathrm{CF}$, Gorham ED, et al. Breast cancer risk markedly lower with serum 25 -hydroxyvitamin D concentrations $\geq 60 \mathrm{vs}<20 \mathrm{ng} / \mathrm{ml}$ ( 150 vs $50 \mathrm{nmol} / \mathrm{L}$ ): Pooled analysis of two randomized trials and a prospective cohort. PLOS ONE. 2018;13:e0199265. https:// doi.org/10.1371/journal.pone.0199265

42. Madden JM, Murphy L, Zgaga L, Bennett K. De novo vitamin D supplement use post-diagnosis is associated with breast cancer survival. Breast Cancer Res Treat. 2018;172:179-90. https://doi. org/10.1007/s10549-018-4896-6

43. Mirhosseini N, Vatanparast H, Kimball SM. The association between Serum $25(\mathrm{OH}) \mathrm{D}$ status and blood pressure in participants of a community-based program taking vitamin D supplements. Nutrients. 2017;9:1244.

44. Rusińska A, Płudowski P, Walczak M, Borszewska-Kornacka MK, Bossowski A, Chlebna-Sokół D, et al. Vitamin D supplementation guidelines for general population and groups at risk of vitamin D deficiency in poland-recommendations of the polish society of pediatric endocrinology and diabetes and the expert panel with participation of national specialist consultants and representatives of scientific societies. Front Endocrinol. 2018;9. https://doi.org/10.3389/fendo.2018.00246

45. Dudenkov DV, Yawn BP, Oberhelman SS, Fischer PR, Singh RJ, Cha SS, et al. Changing incidence of serum 25-Hydroxyvitamin D values above $50 \mathrm{ng} / \mathrm{mL}$ : a 10 -year population-based study. Mayo Clin Proc. 2015;90:577-86. https://doi.org/10.1016/j.mayocp.2015. 02.012

46. Holick MF. Vitamin D is not as toxic as was once thought: a historical and an up-to-date perspective. Mayo Clin Proc. 2015;90:561-4. https://doi.org/10.1016/j.mayocp.2015.03.015 
47. Tebben PJ, Singh RJ, Kumar R. Vitamin D-mediated hypercalcemia: mechanisms, diagnosis, and treatment. Endocr Rev. 2016;37:521-47. https://doi.org/10.1210/er.2016-1070

48. Jones G. Pharmacokinetics of vitamin D toxicity. Am J Clin Nutr. 2008;88:582S-586S. https://doi.org/10.1093/ajcn/88.2.582S

49. Jacobus CH, Holick MF, Shao Q, Chen TC, Holm IA, Kolodny $\mathrm{JM}$, et al. Hypervitaminosis D associated with drinking milk. N. Engl J Med. 1992;326:1173-7. https://doi.org/10.1056/ nejm199204303261801

50. Jääskeläinen T, Itkonen ST, Lundqvist A, Erkkola M, Koskela T, Lakkala $\mathrm{K}$, et al. The positive impact of general vitamin $\mathrm{D}$ food fortification policy on vitamin D status in a representative adult Finnish population: evidence from an 11-y follow-up based on standardized 25-hydroxyvitamin D data. Am J Clin Nutr. 2017;105:1512-20. https://doi.org/10.3945/ajcn.116.151415

51. Madsen KH, Rasmussen LB, Andersen R, Mølgaard C, Jakobsen $\mathrm{J}$, Bjerrum PJ, et al. Randomized controlled trial of the effects of vitamin D-fortified milk and bread on serum 25-hydroxyvitamin D concentrations in families in Denmark during winter: the VitmaD study. Am J Clin Nutr. 2013;98:374-82. https://doi.org/ 10.3945/ajen.113.059469

52. Hayes A, Duffy S, O'Grady M, Jakobsen J, Galvin K, TeahanDillon $J$, et al. Vitamin D-enhanced eggs are protective of wintertime serum 25-hydroxyvitamin $\mathrm{D}$ in a randomized controlled trial of adults. Am J Clin Nutr. 2016;104:629-37. https:// doi.org/10.3945/ajcn.116.132530

53. Manson JE, Cook NR, Lee I-M, Christen W, Bassuk SS, Mora S, et al. Marine $n-3$ fatty acids and prevention of cardiovascular disease and cancer. N. Engl J Med. 2018;380:23-32. https://doi. org/10.1056/NEJMoa1811403

54. Scragg RKR. Overview of results from the Vitamin D assessment (ViDA) study. J Endocrinol Invest. 2019. https://doi.org/ 10.1007/s40618-019-01056-z

55. Scragg R, Stewart AW, Waayer D, Lawes CMM, Toop L, Sluyter $\mathrm{J}$, et al. Effect of monthly high-dose vitamin D supplementation on cardiovascular disease in the vitamin D assessment study: a randomized clinical trial. JAMA Cardiol. 2017;2:608-16. https://doi. org/10.1001/jamacardio.2017.0175

56. Bischoff-Ferrari H, Vitamin D3-Omega3-home exercisehealthy ageing and longevity trial (DO-HEALTH). ClinicalTrials. gov; 2012. https://clinicaltrials.gov/ct2/show/NCT01745263.

57. Tuomainen T-P, Finnish vitamin D trial (FIND). ClinicalTrials. gov; 2011. https://clinicaltrials.gov/ct2/show/NCT01463813.

58. London School of Hygiene \& Tropical Medicine. Vitamin D and longevity (VIDAL) trial: randomised feasibility study. ISRCTN Registry; 2011. https://doi.org/10.1186/ISRCTN46328341.

59. Schoenmakers I, Francis RM, McColl E, Chadwick T, Goldberg GR, Harle C, et al. Vitamin D supplementation in older people (VDOP): Study protocol for a randomised controlled intervention trial with monthly oral dosing with $12,000 \mathrm{IU}, 24,000 \mathrm{IU}$ or 48,000 IU of vitamin D3. Trials. 2013;14:299. https://doi.org/10. 1186/1745-6215-14-299

60. Ng K, Nimeiri HS, McCleary NJ, Abrams TA, Yurgelun MB, Cleary JM, et al. Effect of high-dose vs standard-dose vitamin D3 supplementation on progression-free survival among patients with advanced or metastatic colorectal cancer: the SUNSHINE randomized clinical trial. JAMA. 2019;321:1370-9. https://doi. org/10.1001/jama.2019.2402

61. Rosendahl J, Valkama S, Holmlund-Suila E, Enlund-Cerullo M, Hauta-alus $\mathrm{H}$, Helve $\mathrm{O}$, et al. Effect of higher vs standard dosage of vitamin D3 supplementation on bone strength and infection in healthy infants: a randomized clinical trial. JAMA Pediatrics. 2018;172:646-54. https://doi.org/10.1001/jamapediatrics.2018. 0602

62. Sluyter JD, Camargo CA Jr., Stewart AW, Waayer D, Lawes CMM, Toop L, et al. Effect of monthly, high-dose, long-term vitamin D supplementation on central blood pressure parameters: a randomized controlled trial substudy. J Am Heart Assoc. 2017;6:e006802. https://doi.org/10.1161/JAHA.117.006802

63. Thompson BT. Vitamin D to improve outcomes by leveraging early treatment (VIOLET). ClinicalTrials.gov; 2017. https:// clinicaltrials.gov/ct2/show/NCT03096314

64. Heaney RP. Guidelines for optimizing design and analysis of clinical studies of nutrient effects. Nutr Rev. 2014;72:48-54. https://doi.org/10.1111/nure.12090

65. Brenner H, Jansen L, Saum K-U, Holleczek B, Schöttker B. Vitamin D supplementation trials aimed at reducing mortality have much higher power when focusing on people with low serum 25hydroxyvitamin D concentrations. J Nutr. 2017;147:1325-33. https://doi.org/10.3945/jn.117.250191

66. Avenell A, Mak JCS, O'Connell D. Vitamin D and vitamin D analogues for preventing fractures in post-menopausal women and older men. Cochrane Database Syst Rev. 2014. https://doi. org/10.1002/14651858.CD000227.pub4

67. Bjelakovic G, Nikolova D, Bjelakovic M, Gluud C. Vitamin D supplementation for chronic liver diseases in adults. Cochrane Database Syst Rev. 2015. https://doi.org/10.1002/14651858. CD011564

68. Pludowski P, Holick MF, Pilz S, Wagner CL, Hollis BW, Grant WB, et al. Vitamin D effects on musculoskeletal health, immunity, autoimmunity, cardiovascular disease, cancer, fertility, pregnancy, dementia and mortality-A review of recent evidence. Autoimmun Rev. 2013;12:976-89. https://doi.org/10. 1016/j.autrev.2013.02.004

69. Bjelakovic G, Gluud LL, Nikolova D, Whitfield K, Wetterslev J, Simonetti RG, et al. Vitamin D supplementation for prevention of mortality in adults. Cochrane Datab Syst Rev. 2014. https:// doi.org/10.1002/14651858.CD007470.pub3

70. Gaksch M, Jorde R, Grimnes G, Joakimsen R, Schirmer H, Wilsgaard T, et al. Vitamin D and mortality: Individual participant data meta-analysis of standardized 25-hydroxyvitamin D in 26916 individuals from a European consortium. PLOS ONE. 2017;12: e0170791. https://doi.org/10.1371/journal.pone.0170791

71. Aspelund T, Grübler MR, Smith AV, Gudmundsson EF, Keppel M, Cotch MF, et al. Effect of genetically low 25-hydroxyvitamin $\mathrm{D}$ on mortality risk: mendelian randomization analysis in 3 large european cohorts. Nutrients. 2019;11:74. https://doi.org/10.3390/ nu11010074

72. Berlanga-Taylor AJ, Leclair TR, Zakai N, Bunn JY, Gianni M, Heyland DK, et al. Vitamin D supplementation in mechanically ventilated patients in the medical intensive care unit. BMJ Open. 2019. https://doi.org/10.1136/bmjopen-2018-02766610.1002/jpen.

73. Quraishi SA, De Pascale G, Needleman JS, Nakazawa H, Kaneki M, Bajwa EK. et al. Effect of cholecalciferol supplementation on vitamin D status and cathelicidin levels in sepsis: a randomized, placebo-controlled trial. Crit Care Med. 2015;43:1928-37. https:// doi.org/10.1111/ene.1278810.1097/ccm.0000000000001148.

74. Palacios C, Trak-Fellermeier MA, Martinez RX, Lopez-Perez L, Lips P, Salisi JA. et al. Regimens of vitamin D supplementation for women during pregnancy. Cochrane Database Syst Rev. 2019;10:Cd013446 https://doi.org/10.1002/14651858.cd013446. e-pub ahead of print 2019/10/04.

75. Palacios C, Kostiuk LK, Pena-Rosas JP. Vitamin D supplementation for women during pregnancy. Cochrane Database Syst Rev. 2019;7:Cd008873 https://doi.org/10.1002/14651858. CD008873.pub4. e-pub ahead of print 2019/07/28.

76. Holick MF. A call to action: pregnant women in-deed require vitamin D supplementation for better health outcomes. J Clin Endocrinol Metab. 2018;104:13-15. https://doi.org/10.1210/jc. 2018-01108

77. Mithal A, Wahl DA, Bonjour J-P, Burckhardt P, Dawson-Hughes B, Eisman JA, et al. Global vitamin D status and determinants of 
hypovitaminosis D. Osteoporos Int. 2009;20:1807-20. https://doi. org/10.1007/s00198-009-0954-6

78. Fogacci S, Fogacci F, Banach M, Michos ED, Hernandez AV, Lip GYH, et al. Vitamin D supplementation and incident preeclampsia: a systematic review and meta-analysis of randomized clinical trials. Clin Nutr. 2019. https://doi.org/10.1016/j.clnu. 2019.08.015

79. Rodrigues MRK, Lima SAM, Mazeto GMFDSS, Calderon IMP, Magalhães CG, Ferraz GAR. et al. Mazeto GMFdS, Calderon IMP, Magalhães CG, Ferraz GAR et al. Efficacy of vitamin D supplementation in gestational diabetes mellitus: systematic review and meta-analysis of randomized trials. PLOS ONE. 2019;14:e0213006. https://doi.org/10.1371/journal.pone.0213006.

80. Akbari S, Khodadadi B, Ahmadi SAY, Abbaszadeh S, Shahsavar F. Association of vitamin D level and vitamin D deficiency with risk of preeclampsia: a systematic review and updated metaanalysis. Taiwan J Obstet Gynecol. 2018;57:241-7. https://doi. org/10.1016/j.tjog.2018.02.013

81. McDonnell SL, Baggerly KA, Baggerly CA, Aliano JL, French $\mathrm{CB}$, Baggerly LL, et al. Maternal 25(OH)D concentrations $\geq 40 \mathrm{ng} / \mathrm{mL}$ associated with $60 \%$ lower preterm birth risk among general obstetrical patients at an urban medical center. PloS ONE. 2017;12:e0180483-e0180483. https://doi.org/10.1371/ journal.pone. 0180483

82. Wagner CL, Baggerly C, McDonnell S, Baggerly KA, French $\mathrm{CB}$, Baggerly L. et al. Post-hoc analysis of vitamin D status and reduced risk of preterm birth in two vitamin D pregnancy cohorts compared with South Carolina March of Dimes 2009-211 rates. J Steroid Biochem Mol Biol. 2016;155:245-51. https://doi.org/ 10.1016/j.jsbmb.2015.10.022.

83. Hollis BW, Johnson D, Hulsey TC, Ebeling M, Wagner CL. Vitamin D supplementation during pregnancy: double-blind, randomized clinical trial of safety and effectiveness. J Bone Min Res. 2011;26:2341-57. https://doi.org/10.1002/jbmr.463

84. Rostami M, Tehrani FR, Simbar M, Bidhendi Yarandi R, Minooee S, Hollis BW, et al. Effectiveness of prenatal vitamin D deficiency screening and treatment program: a stratified randomized field trial. J Clin Endocrinol Metab. 2018;103:2936-48. https://doi.org/10.1210/jc.2018-00109

85. Hossein-nezhad A, Holick MF. Optimize dietary intake of vitamin D: an epigenetic perspective. Curr Opin Clin Nutr Metab Care. 2012;15:567-79. https://doi.org/10.1097/MCO. 0b013e3283594978

86. Novakovic B, Sibson M, Ng HK, Manuelpillai U, Rakyan V, Down T, et al. Placenta-specific methylation of the vitamin D 24hydroxylase gene: implications for feedback autoregulation of active vitamin D levels at the fetomaterial interface. J Biol Chem. 2009;284:14838-48. https://doi.org/10.1074/jbc.M809542200

87. McDonnell SL, Baggerly C, French CB, Baggerly LL, Garland $\mathrm{CF}$, Gorham ED, et al. Serum 25-hydroxyvitamin D concentrations $\geq 40 \mathrm{~g} / \mathrm{ml}$ are associated with $>65 \%$ lower cancer risk: pooled analysis of randomized trial and prospective cohort study. PLOS ONE. 2016;11:e0152441 https://doi.org/10.1371/journal. pone. 0152441

88. Colston K, Colston MJ, Feldman D. 1,25-Dihydroxyvitamin D3 and malignant melanoma: the presence of receptors and inhibition of cell growth in culture. Endocrinology. 1981;108:1083-6. https://doi.org/10.1210/endo-108-3-1083

89. Garland CF, Garland FC. Do sunlight and vitamin D reduce the likelihood of colon cancer? Int J Epidemiol. 1980;9:227-31. https://doi.org/10.1093/ije/9.3.227

90. Keum N, Giovannucci E. Vitamin D supplements and cancer incidence and mortality: a meta-analysis. $\mathrm{Br} \mathrm{J}$ Cancer. 2014;111:976. https://doi.org/10.1038/bjc.2014.294

91. Bjelakovic G, Gluud LL, Nikolova D, Whitfield K, Krstic G, Wetterslev J, et al. Vitamin D supplementation for prevention of cancer in adults. Cochrane Database Syst Rev. 2014. https://doi. org/10.1002/14651858.CD007469.pub2

92. Lappe J, Watson P, Travers-Gustafson D, Recker R, Garland C, Gorham E, et al. Effect of vitamin D and calcium supplementation on cancer incidence in older women: a randomized clinical trial. JAMA. 2017;317:1234-43. https://doi.org/10.1001/ jama.2017.2115

93. Chatterjee R, Erban JK, Fuss P, Dolor R, LeBlanc E, Staten M, et al. Vitamin D supplementation for prevention of cancer: the D2d cancer outcomes (D2dCA) study. Contemp Clin Trials. 2019;81:62-70. https://doi.org/10.1016/j.cct.2019.04.015

94. Greer RM, Portelli SL, Hung BS-M, Cleghorn GJ, McMahon SK, Batch JA, et al. Serum vitamin D levels are lower in Australian children and adolescents with type 1 diabetes than in children without diabetes. Pediatr Diabetes. 2013;14:31-41. https://doi.org/10.1111/j.1399-5448.2012.00890.x

95. Daga RA, Laway BA, Shah ZA, Mir SA, Kotwal SK, Zargar AH. High prevalence of vitamin D deficiency among newly diagnosed youth-onset diabetes mellitus in north India. Arquivos Brasileiros de Endocrinologia Metabologia. 2012;56:423-8.

96. Federico G, Genoni A, Puggioni A, Saba A, Gallo D, Randazzo $\mathrm{E}$, et al. Vitamin D status, enterovirus infection, and type 1 diabetes in Italian children/adolescents. Pediatr Diabetes. 2018;19:923-9. https://doi.org/10.1111/pedi.12673

97. Rasoul MA, Al-Mahdi M, Al-Kandari H, Dhaunsi GS, Haider MZ. Low serum vitamin D status is associated with high prevalence and early onset of type-1 diabetes mellitus in Kuwaiti children. BMC Pediatr. 2016;16:95-95. https://doi.org/10.1186/ s12887-016-0629-3

98. Sørensen IM, Joner G, Jenum PA, Eskild A, Torjesen PA, Stene LC. Maternal serum levels of 25-hydroxy-vitamin D during pregnancy and risk of type 1 diabetes in the offspring. Diabetes. 2012;61:175. https://doi.org/10.2337/db11-0875

99. Jacobsen R, Moldovan M, Vaag AA, Hypponen E, Heitmann BL. Vitamin D fortification and seasonality of birth in type 1 diabetic cases: D-tect study. J Devel Orig Health Dis. 2016;7:114-9. https://doi.org/10.1017/S2040174415007849. epub ahead of print 2015/10/27.

100. Dong J-Y, Zhang W, Chen JJ, Zhang Z-L, Han S-F, Qin L-Q. Vitamin D intake and risk of type 1 diabetes: a meta-analysis of observational studies. Nutrients. 2013;5:3551-62.

101. Stene LC, Joner G, Group NCDS. Use of cod liver oil during the first year of life is associated with lower risk of childhood-onset type 1 diabetes: a large, population-based, case-control study. Am J Clin Nutr. 2003;78:1128-34. https://doi.org/10.1093/ajcn/ 78.6.1128

102. Raab J, Giannopoulou EZ, Schneider S, Warncke K, Krasmann M, Winkler C, et al. Prevalence of vitamin D deficiency in pre-type 1 diabetes and its association with disease progression. Diabetologia. 2014;57:902-8. https://doi.org/10.1007/s00125-014-3181-4

103. Mäkinen M, Mykkänen J, Koskinen M, Simell V, Veijola R, Hyöty H, et al. Serum 25-hydroxyvitamin D concentrations in children progressing to autoimmunity and clinical type 1 diabetes. J Clin Endocrinol Metab. 2016;101:723-9. https://doi.org/ 10.1210/jc.2015-3504

104. Simpson M, Brady H, Yin X, Seifert J, Barriga K, Hoffman M, et al. No association of vitamin D intake or 25-hydroxyvitamin D levels in childhood with risk of islet autoimmunity and type 1 diabetes: the Diabetes Autoimmunity Study in the Young (DAISY). Diabetologia. 2011;54:2779. https://doi.org/10.1007/ s00125-011-2278-2

105. Rak K, Bronkowska M. Immunomodulatory effect of vitamin D and its potential role in the prevention and treatment of type 1 diabetes mellitus-a narrative review. Molecules. 2018;24:53.

106. Thrailkill KM, Jo C-H, Cockrell GE, Moreau CS, Fowlkes JL. Enhanced excretion of vitamin D binding protein in type 1 
diabetes: a role in vitamin D deficiency? J Clin Endocrinol Metab. 2011;96:142-9. https://doi.org/10.1210/jc.2010-0980

107. Kayaniyil S, Vieth R, Retnakaran R, Knight JA, Qi Y, Gerstein $\mathrm{HC}$, et al. Association of vitamin $\mathrm{d}$ with insulin resistance and $\beta$-Cell dysfunction in subjects at risk for type 2 diabetes. Diabetes Care. 2010;33:1379-81. https://doi.org/10.2337/ dc09-2321

108. Kawahara T, Suzuki G, Inazu T, Mizuno S, Kasagi F, Okada Y, et al. Rationale and design of Diabetes Prevention with active Vitamin D (DPVD): a randomised, double-blind, placebocontrolled study. BMJ Open. 2016;6:e011183. https://doi.org/ 10.1136/bmjopen-2016-011183

109. Galior K, Grebe S, Singh R. Development of vitamin D toxicity from overcorrection of vitamin $\mathrm{D}$ deficiency: a review of case reports. Nutrients. 2018;10:953.
110. Schlingmann KP, Kaufmann M, Weber S, Irwin A, Goos C, John U, et al. Mutations in CYP24A1 and Idiopathic Infantile Hypercalcemia. N Engl J Med. 2011;365:410-21. https://doi.org/ 10.1056/NEJMoa1103864

111. National Heart, Lung, and Blood Institute, PETAL Clinical Trials Network, Ginde A, Brower R, et al. Early high-dose vitamin D3 for critically Ill, vitamin D-deficient patients. N Engl J Med. 2019. https://doi.org/10.1056/NEJMoa1911124

112. Amrein K, Schnedl C, Holl A, Riedl R, Christopher KB, Pachler $\mathrm{C}$, et al. Effect of high-dose vitamin D3 on hospital length of stay in critically Ill patients with vitamin D deficiency: the VITdALICU randomized clinical trial. JAMA. 2014;312:1520-30. https://doi.org/10.1001/jama.2014.13204

113. BMJ Open. 2019;9:e031083. https://doi.org/10.1136/bmjopen2019-031083 